\title{
Primer in B2B brand-building strategies with a reader practicum
}

\author{
Mark S. Glynn * \\ Auckland University of Technology, Private Bag 92006, Auckland, New Zealand
}

\section{A R T I C L E I N F O}

Article history:

Accepted 1 March 2011

Available online 14 April 2011

\section{Keywords:}

Business-to-business brands

Resources

Brand value chain

Empirical research

\begin{abstract}
A B S T R A C T
This primer examines the empirical evidence about business-to-business (B2B) brands and its implications for brand strategy. Some of world's most valuable brands are predominantly B2B in nature, however brand marketing texts typically assume a consumer branding (B2C) perspective. The question arises as to whether or not branding is important in B2B marketing. This primer considers the following question. How do B2B brands create and deliver value for firms in inter-organizational transactions? The paper begins by examining the relevance of current theoretical frameworks of branding to B2B value creation. Next the study considers the brand value chain and the contribution of extant B2B research at its various stages. The paper concludes by examining areas for future research in B2B branding and presents a reader practicum.
\end{abstract}

(c) 2011 Elsevier Inc. All rights reserved.

\section{Introduction}

Many entries in the Interbrand (2010) Best Global Brands list are business-to-business (B2B) brands including five of the top ten: GE, IBM, Intel, Microsoft, and HP. Looking further down this list, at least 21 other brands earn substantial revenue from B2B markets. These B2B brands are: Cisco, Oracle, SAP, JP Morgan, UPS, HSBC, Goldman Sachs, Thomson Reuters, Citi, Accenture, Siemens, Morgan Stanley, Axa, Xerox, Allianz, Caterpillar, Credit Suisse, Barclays, UBS, 3M and Zurich. The value of these B2B brands is greater than higher profile consumer brands such as Starbucks, Harley Davidson, and Campbells.

However, many researchers and practitioners regard brand management as being less important in B2B marketing. Early research shows that industrial firms had less brand value as a proportion of intangible asset value than did consumer goods firms (Simon and Sullivan, 1993). Later research calculates the average brand value as a proportion of market capitalization as being 37\% (Madden et al., 2006). However Madden et al. (2006) data confirms that the average value of the top five B2B brands mentioned above is only 19\% of market capitalization. Other research shows that the value of B2B brands varies within the same industry and some firms were using their brands more effectively than their competitors (Gregory and Sexton, 2007). Examples of industries where larger inter-firm brand value differences occurred were computer software, transportation and medical supplies.

An inspection of the Interbrand list shows that B2B brands are prominent in the high technology and financial services sectors. The size and diversity of the B2B firms means that many of these brands

\footnotetext{
The author's solution to the reader practicum is available by request.

* Tel.: + $6499219999 \times 5813$.

E-mail address: mark.glynn@aut.ac.nz.
}

also operate successfully in consumer markets. Furthermore, some B2B brands such as Cisco, Xerox, and Caterpillar that do not have the end-consumer as their primary customer are also meaningful to consumer segments. Thus the traditional divisions between B2B and consumer brand (B2C) firms are blurred as firms use the brand equity created in one channel to leverage their business in other channels.

Although the Interbrand list demonstrates the importance of B2B branding, many commentators apply a B2C branding lens when examining branding from an organizational buying perspective. For instance, Lamons' book on B2B branding discusses brand architecture, brand personality and brand positioning which are all staple topics in consumer branding texts (Lamons, 2005). The disadvantage of applying a $\mathrm{B} 2 \mathrm{C}$ brand perspective to $\mathrm{B} 2 \mathrm{~B}$ brands is that the specialized nature of business marketing and purchasing is sometimes ignored.

Business marketing and purchasing differs from end-consumer buying in many respects. First the value of the transaction is much larger involving raw materials and parts, capital items, operating supplies and maintenance items (Kotler and Pfoertsch, 2006). Second the complexity of the buying process often involves groups of individuals in the firm including buying committees and not just the purchasing manager. Third the buyer is often not the end user. Furthermore the customer firm's production process may incorporate suppliers' brands such as OEMs or the suppliers' brands may be resold by a distributor.

These differences mean that purchasing managers need to focus on the total value of the brand to the firm and its processes, rather than simply scrutinize the price of the goods or services purchased. B2B transactions are also motivated by derived demand, there are fewer customers and there is an emphasis on longer term partnerships. Thus the $\mathrm{B} 2 \mathrm{~B}$ brand purchase can be pivotal in terms of its financial importance for the selling firm and have considerable impact on the B2B customer's business. An example of such a purchase is the ordering of passenger aircraft by the airline industry. 
Business marketing texts including Anderson and Narus (2004) now emphasize the value of branding in inter-organizational exchanges. The benefits of B2B branding for the selling firm include better information efficiency particularly with complex products or services as branded products make information gathering easier. Brands also reduce the chances of a poor purchase decision and reduce business risk. Moreover brands can enhance the experience for the purchaser which is an image benefit (Kotler and Pfoertsch, 2006). These benefits focus on the purchaser. Such benefits are underpinned by the need of the firm to create value for the business customer (Anderson and Narus, 2004).

Creating such value for customers leads to encouraging selling opportunities, increasing likelihood of purchase, reducing time to close the sale, receiving a larger share of the purchase requirement, becoming less resistant to price increases and less willing to trial competitive offerings (Anderson and Narus, 2004). B2B brands also provide functional benefits to the selling firm, such as internal identification for inventory purposes and legal protection through trademarks. In addition, these benefits provide firms with reliable earnings and allow marketing expenditure to be directed towards these brands. Brands enhance the volatility and vulnerability of cashflow within the organization and are an important firm resource. Thus these B2B brand benefits lead to more profitable business relationships.

This article examines the relevance of $\mathrm{B} 2 \mathrm{C}$ branding frameworks to $\mathrm{B} 2 \mathrm{~B}$ brands together with some alternative perspectives. The article presents a brand value chain showing the stages in the brand building process. The article examines relevant literature for each of these key stages on building B2B brands and offers suggestions for future research. The end of the article includes a reader practicum. This practicum allows readers to apply the lessons from this study.

\section{The relevance of $\mathrm{B} 2 \mathrm{C}$ frameworks for $\mathrm{B} 2 \mathrm{~B}$ brands}

Key issues for a B2B brand marketer include the following questions. How does branding benefit the firm? Are brand-building marketing expenditures justifiable? For consumer marketers, brands improve the efficiency of marketing expenditure, create more loyalty, allow a price premium to be charged and provide a platform for further brand extensions or new lines to be introduced under the brand name. Lee et al. (2008) investigate whether or not the existence of a brand management approach benefits B2B customers. Such a brand management system includes the CEO's interest in the brand, the brand manager's power, employee education and training. Their research shows that the effect of a brand management system was stronger for $\mathrm{B} 2 \mathrm{~B}$ brands on customer preference in comparison to $\mathrm{B} 2 \mathrm{C}$ brands.

Kotler and Pfoertsch (2006) use Kevin Keller's customer-based brand equity (CBBE) model to explain the B2B branding process. Brand equity is the differential advantage of the branded product compared to the identical unbranded product. This differential is known as brand knowledge and consists of brand awareness and brand image (Keller, 2008). Brand awareness is whether a customer has heard about a brand, whereas the brand image consists of the attributes and benefits that buyers associate with a brand. Strong brands have a rational as well as an emotional appeal and the result of this brand building effort is customer attachment or loyalty to the brand. Another perspective is Erdem and Swait's model which focuses on the credibility of the brand signal sent to prospective customers. This signal consists of a brand's perceived quality, risk of purchase and information gathering costs. Many B2B brand researchers apply B2C frameworks for example Michell et al. (2001).

Some commentators however question the relevance of $\mathrm{B} 2 \mathrm{C}$ frameworks to the industrial buying process with their emphasis on consumer psychology and information economics. Researchers suggest the applicability of the emotional and self-expressive di- mensions from Keller's framework such as customer feelings towards a brand are less relevant to B2B brands (Kuhn et al., 2008). There are subtle branding differences in B2B marketing including an emphasis on corporate rather than product branding and more emphasis on risk reduction (Mudambi, 2002).

Researchers call for a better understanding of a broader process of brand equity development involving other stakeholders, rather than just focusing on brands and customers. The meaning of the term brand equity is much wider and includes relational, network (cobranding and alliances) and financial (Brodie et al., 2006). Similarly Anderson and Narus (2004) propose a broader perspective which includes brand equity (linking brands and consumers), channel equity (links with resellers), reseller equity (resellers' links with the endcustomer) which together create market-place equity.

The framework of Srivastava et al. (1998) explains that brands are important market-based (intangible) assets which help build external relationships in the market-place. The market-based assets framework is based on the resource-based view of the firm and shows the effects of B2B branding among stakeholders. Resources are valuable to firms if they have value, are rare and not able to be imitated or substituted. Brands satisfy this resource criteria as they have value, are unique to the selling firm and are not easily substituted.

As a firm resource, brands influence external business relationships and enhance shareholder performance (Srivastava et al., 1998). For B2B marketers brands function as a resource tie between suppliers and customers (Ford, 1998). This resource tie determines the level of investment a firm can allocate to their brands. For instance a private label brand supplier does not have to support that brand with marketing expenditure, but the success of the brand depends on the retailer's efforts.

The resource-based view also underpins the service dominant logic which views the brand as an operant resource (Vargo and Lusch, 2004). An operant resource is one that firms can use to act on other resources. Here the provision of goods and services are seen as a distribution mechanism for service to the customer. Furthermore the industrial buyer co-creates value with the seller before the purchase through providing purchasing specifications or supplier briefings. This brand value may be confirmable through direct experience of the brand or indirectly through interaction or communication with other stakeholders (Ballantyne and Aitken, 2007).

In the service brand context, Brodie et al. (2006) also view the brand as a resource that facilitates and directs the relationship between its employees, company and its customers. Moreover these brand resource processes are dynamic and interactive and involve other stakeholders (Merz et al., 2009). These frameworks suggest that B2B brand researchers should consider wider perspectives than just the brand to customer linkage. The next section examines extant research which addresses how B2B brands are built within these broader value creation processes.

\section{Building the B2B brand}

To capture the value creation process for brands, Keller and Lehmann (2003) devise the brand value chain shown in Fig. 1. For B2B brands, the process begins with the firm's marketing program directed at potential customers. This marketing program affects the B2B customer mindset or brand equity. Success with customers or the creation of brand equity is reflected in an enhanced market performance. Superior market performance of the brand in turn creates shareholder value. An important aspect to note is that success at each stage may be either enhanced or inhibited by multipliers. Examples of multipliers include the quality of the marketing program which may build customer awareness of the brand, channel support and competitor actions which affect B2B brand market performance. Research shows that leading brands can deliver above average shareholder returns (Madden et al., 2006). 


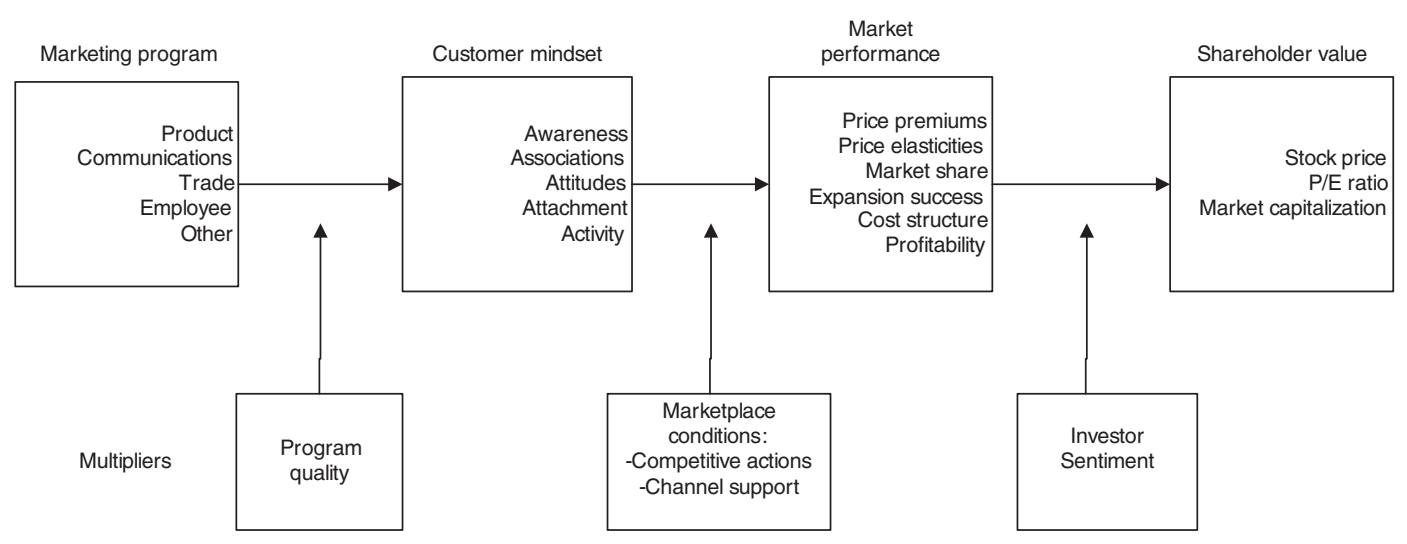

Fig. 1. Brand value chain - value stages (Keller and Lehmann, 2003).

\section{B2B brand marketing program}

Much of the early research into B2B branding examines whether or not branding was worthwhile for the B2B marketer. Table 1 summarizes the research studies that focus on B2B marketing program investments.

Early studies suggest that branding may be of little value (Saunders and Watt, 1979). Industrial firms see more benefit for their own company of branding, but often consider this benefit as being less relevant for their customers. Shipley and Howard (1993) report that larger firms viewed branding as beneficial, but only two customer benefits "value to customers" and "making the purchase easier" were mentioned. Additional research by Michell et al. (2001) shows managers thought industrial brands provide image consistency and are useful in customer communication.

Another B2B branding decision is whether or not firms should produce their own brand or produce a private label for another customer. Research in the fine paper supply chain, shows that producing your own brand can involve additional resources such as marketing expenditure. However, private label production means fewer marketing resources are involved, but the supplier is more dependent on the distributor (Rosenbröijer, 2001).

Research shows that the brand name is only part of the industrial purchase decision. In the study of Gordon et al. (1993), electrical contractors ranked brands fourth out of six factors that influence their choice of distributors for electrical switches. In this research the supplier had stopped direct customer sales, so the task of creating brand awareness (providing sales leaflets) was left to distributors. Buyers in the study of Bendixen et al. (2004) ranked price and delivery ahead of the brand name in the purchase decision. In contrast, when farmers and farm contractors considered purchasing tractors, research shows the brand name accounted for the highest proportion of the decision compared to the price, dealer and service quality attributes (Walley et al., 2007). Sinclair and Seward (1988) in their study of wood manufacturers found that suppliers thought that brands were important for recognition. However their related study of wood product retailers highlighted relatively weak brand awareness of manufacturer brands (Sinclair and Seward, 1988).

Early research also shows that industrial buyers value the intangible benefits as well as the functional benefits provided by sellers. Shaw et al. (1989) found that when complex industrial products such as mainframe computers were purchased, intangible attributes were more important than product performance attributes, because of the future uncertainty about product developments in that industry. Another study which includes salmon feed suppliers and telephone business customers shows that performance quality affected brand reputation and hence brand loyalty. However for business customers satisfaction had no effect on brand reputation (Selnes, 1993). The importance of brand intangibles was also illustrated in the B2B services context where large switching costs often encourages buyers to remain loyal (Yanamandram and White, 2006).

Mudambi et al. (1997) report that as well as product considerations, industrial buyers of precision bearings viewed support, delivery and corporate services as also important. Glynn et al. (2007) demonstrate that the marketing program associated with the brand was seen as a resource benefit for supermarket buyers. Manufacturer brands offer retailers several benefits: financial (providing a means for profit), consumer brand support, customer benefits (the store expects the retailer to carry that brand) and the certainty of demand created by brand equity. These benefits were connected to the brand name and impact on resellers' perception of the brand.

Research shows suppliers of steel laser cutters focus on solving technical, logistic problems and providing support for customers (McQuiston, 2004). In this instance the brand name also reflects the corporate and service orientation to the customer. B2B brands also allow industrial buyers to reduce the time spent in selecting alternatives and are less risky in terms of resolving technical and internal production problems. These benefits create value for the buyer and the firm's reputation and encompass product aspects such as no defects, distribution aspects such as just in time and reliable delivery, support services such as problem-solving advice and world class expertise (Mudambi, 2002). The multidimensional nature of the B2B brand offering and the emphasis on the corporate brand contrasts with consumer marketing where the focus is often on the product brand.

Corporate brand and product brand knowledge have different effects on B2B customer loyalty (van Riel et al., 2005). van Riel et al. (2005) show that the product value and distribution aspects of the purchase influence product brand equity, while components such as buyer information and company personnel influence the service component and corporate brand equity. Cretu and Brodie (2007) findings also confirm that product brand image influences the product and service features of the market offering, while corporate reputation influences the more global concerns of the buyer such as customer value.

With the greater emphasis on corporate branding and service, employees are important in the B2B marketing program. Baumgarth and Schmidt (2010) investigate how employees viewed the brand in terms of knowledge, involvement and commitment (internal brand equity). Their research shows that internal brand equity influenced how B2B customers viewed the brand. Lambkin and Muzellec (2010) show that internal rebranding by B2B firms was not only important for building distribution networks and sales force relationships, but also sent a positive message to employees and the stock market.

Gupta et al. (2010) report that in B2B brand selection, brand representatives, individuals from the selling firm who educate and inform buyers about the brand, are important in developing 
Table 1

B2B brand marketing program research.

\begin{tabular}{|c|c|c|c|c|}
\hline Author(s) & Sample & Independent variables & Dependent variables & Key findings \\
\hline Saunders and Watt (1979) & $\begin{array}{l}100 \text { female consumers and } 29 \\
\text { managers of textile firms. } \\
\text { Survey. }\end{array}$ & $\begin{array}{l}\text { Brand comprehension } \\
\text { Personal attitudes } \\
\text { Intention } \\
\text { Confidence }\end{array}$ & $\begin{array}{l}\text { Purchase decision } \\
\text { Satisfaction }\end{array}$ & $\begin{array}{l}\text { Branding alone is unlikely to be of } \\
\text { value in the market. } \\
\text { Brand strategies can be confusing } \\
\text { and have mixed effectiveness. }\end{array}$ \\
\hline Sinclair and Seward (1988) & $\begin{array}{l}19 \text { wood manufacturers, } 386 \\
\text { retailers. } \\
\text { Survey. }\end{array}$ & $\begin{array}{l}\text { Price } \\
\text { Availability } \\
\text { Performance } \\
\text { Customer preference } \\
\text { Service } \\
\text { Reliable, } \\
\text { Product appearance }\end{array}$ & Brand selection criteria & $\begin{array}{l}\text { Weak brand awareness was found } \\
\text { among retailers } \\
\text { Branding: enhances } \\
\text { differentiation, promotes } \\
\text { recognition and promotes loyalty. }\end{array}$ \\
\hline Shaw et al. (1989) & $\begin{array}{l}100 \text { management information } \\
\text { systems executives. } \\
\text { Survey. }\end{array}$ & $\begin{array}{l}\text { Purchase attributes - } \\
\text { Physical: } \\
\text { System performance monitoring, } \\
\text { Built-in high security, } \\
\text { Office automation systems } \\
\text { compatibility, } \\
\text { Throughput levels, } \\
\text { Continuous operation. } \\
\text { Psychological: } \\
\text { Credibility, system growth, single } \\
\text { source for systems integration, } \\
\text { continuous development OS } \\
\text { supplier, vendor provided } \\
\text { support, vendors understanding of } \\
\text { environment, in house personnel } \\
\text { availability who know the OS. }\end{array}$ & Purchase decision & $\begin{array}{l}\text { The results suggest that once } \\
\text { physical performance criteria are } \\
\text { met, big ticket industrial buying } \\
\text { decisions are largely based on } \\
\text { psychological factors. Therefore, } \\
\text { successful industrial marketing } \\
\text { should include more emphasis on } \\
\text { the psychological aspects of the } \\
\text { buying decision. Buyer concerns } \\
\text { over uncertainty in future } \\
\text { developments are important. }\end{array}$ \\
\hline Shipley and Howard (1993) & $\begin{array}{l}135 \text { marketing managers from UK } \\
\text { industrial product firms. } \\
\text { Survey. }\end{array}$ & $\begin{array}{l}\text { Product identity } \\
\text { Important in marketing success } \\
\text { Asset to firm } \\
\text { Makes buying easier } \\
\text { Useful in positioning and } \\
\text { segmentation } \\
\text { Gives competitive edge } \\
\text { Value to customers } \\
\text { Legal protection } \\
\text { Helps in order processing }\end{array}$ & $\begin{array}{l}\text { Perceptions of brand name } \\
\text { benefits }\end{array}$ & $\begin{array}{l}\text { Large industrial firms value the } \\
\text { benefits of brand names, and } \\
\text { attach more importance to brand } \\
\text { names. }\end{array}$ \\
\hline Gordon et al. (1993) & $\begin{array}{l}114 \text { electrical contractors } \\
\text { purchasing electrical equipment. } \\
\text { Survey. }\end{array}$ & $\begin{array}{l}\text { Price } \\
\text { Credit policies } \\
\text { Relationship } \\
\text { Location } \\
\text { Able to meet deadlines } \\
\text { Brands carried }\end{array}$ & Choice of distributor & $\begin{array}{l}\text { A range of factors influence the } \\
\text { choice of distributor. } \\
\text { Meeting deadlines, price, and } \\
\text { relationship were most important } \\
\text { followed by brand. }\end{array}$ \\
\hline Selnes (1993) & $\begin{array}{l}125 \text { Salmon feed suppliers } 395 \\
\text { business phone customers. } \\
\text { Survey. }\end{array}$ & $\begin{array}{l}\text { Performance quality } \\
\text { Brand reputation } \\
\text { Satisfaction } \\
\text { Loyalty }\end{array}$ & Brand loyalty & $\begin{array}{l}\text { Performance quality affects brand } \\
\text { reputation. } \\
\text { Brand reputation affects brand } \\
\text { loyalty. }\end{array}$ \\
\hline Mudambi et al. (1997) & $\begin{array}{l}15 \text { managers in precision bearings } \\
\text { market. } \\
\text { Interviews. }\end{array}$ & $\begin{array}{l}\text { Product } \\
\text { Distribution } \\
\text { Support } \\
\text { Company }\end{array}$ & Brand sources of value & $\begin{array}{l}\text { Both intangible (especially } \\
\text { company) attributes as well as } \\
\text { tangible aspects of industrial } \\
\text { brands are important. }\end{array}$ \\
\hline Michell et al. (2001) & $\begin{array}{l}70 \text { chief executives in engineering, } \\
\text { electronics, chemicals, plastics and } \\
\text { paper. } \\
\text { Survey. }\end{array}$ & $\begin{array}{l}\text { Confidence in decision } \\
\text { Enhance corporate } \\
\text { reputation } \\
\text { Competitive advantage } \\
\text { Company creditability } \\
\text { Barriers to entry } \\
\text { Price premium } \\
\text { Scope for line extension } \\
\text { More marketing expenditure } \\
\text { Customer commitment }\end{array}$ & $\begin{array}{l}\text { Competitive differential of } \\
\text { industrial brands }\end{array}$ & $\begin{array}{l}\text { Branding generates differential } \\
\text { marketing benefits. } \\
\text { Enhances confidence in the } \\
\text { purchase decision. } \\
\text { Intangible aspects of purchase } \\
\text { important. }\end{array}$ \\
\hline Rosenbröijer (2001) & $\begin{array}{l}9 \text { executives in the fine paper } \\
\text { industry. } \\
\text { Case study. }\end{array}$ & $\begin{array}{l}\text { Resource intra-dependence } \\
\text { Resource inter-dependence } \\
\text { Resource connections }\end{array}$ & $\begin{array}{l}\text { Analyzed at the company } \\
\text { Relationship and network level }\end{array}$ & $\begin{array}{l}\text { Shows the dependence of the } \\
\text { distributor on the brand } \\
\text { manufacturer and their marketing } \\
\text { resources. } \\
\text { For the private label research } \\
\text { showed the dependence on the } \\
\text { distributor marketing capability. } \\
\text { Examined relationship effects of } \\
\text { each decision. }\end{array}$ \\
\hline Mudambi (2002) & $\begin{array}{l}116 \text { UK industrial buyers of } \\
\text { precision bearings. } \\
\text { Survey. }\end{array}$ & $\begin{array}{l}\text { Need/benefits } \\
\text { Purchase characteristics } \\
\text { Buyer characteristics } \\
\text { Attribute importance (brand) }\end{array}$ & Choice & $\begin{array}{l}\text { Three clusters of buyers exist: } \\
\text { brand receptive } 37 \% \text {, those } \\
\text { concerned with highly tangible } \\
\text { aspect of offer } 49 \% \text { and low } \\
\text { interest in purchase } 14 \% \text {. }\end{array}$ \\
\hline
\end{tabular}


Table 1 (continued)

\begin{tabular}{|c|c|c|c|c|}
\hline Author(s) & Sample & Independent variables & Dependent variables & Key findings \\
\hline Bendixen et al. (2004) & $\begin{array}{l}54 \text { decision-makers of electrical } \\
\text { equipment companies. } \\
\text { Conjoint analysis. }\end{array}$ & $\begin{array}{l}\text { Brands } \\
\text { Prices } \\
\text { Delivery } \\
\text { Technology, and } \\
\text { Spares lead time. }\end{array}$ & $\begin{array}{l}\text { Importance of attributes } \\
\text { Brand preference. }\end{array}$ & $\begin{array}{l}\text { Price and delivery more important } \\
\text { than brand. } \\
\text { However, a price premium can be } \\
\text { obtained from high brand equity } \\
\text { brands. }\end{array}$ \\
\hline van Riel et al. (2005) & $\begin{array}{l}75 \text { customers of a specialty } \\
\text { chemical company. } \\
\text { Survey. }\end{array}$ & $\begin{array}{l}\text { Value } \\
\text { Distribution } \\
\text { Product } \\
\text { Information } \\
\text { Personnel } \\
\text { Service. }\end{array}$ & $\begin{array}{l}\text { Product and corporate brand } \\
\text { equity } \\
\text { Loyalty intentions }\end{array}$ & $\begin{array}{l}\text { Create a favorable impression of } \\
\text { product. } \\
\text { The corporate brand and service } \\
\text { and the employees is important } \\
\text { Loyalty is driven by a strong } \\
\text { corporate brand. }\end{array}$ \\
\hline $\begin{array}{l}\text { Yanamandram and White } \\
\text { (2006) }\end{array}$ & $\begin{array}{l}28 \text { buyers choosing service } \\
\text { providers. } \\
\text { Interviews. }\end{array}$ & $\begin{array}{l}\text { Respondents were asked about } \\
\text { reasons for dissatisfaction; } \\
\text { whether the service failure was } \\
\text { major or minor; the perceived } \\
\text { barriers that prevented brand } \\
\text { switching and actions taken by the } \\
\text { service provider to prevent } \\
\text { switching. }\end{array}$ & $\begin{array}{l}\text { Behavioral brand loyalty to service } \\
\text { provider }\end{array}$ & $\begin{array}{l}\text { Managers remained brand loyal } \\
\text { because of; impact of alternative } \\
\text { providers, switching costs, inertia, } \\
\text { investment in relationships, and } \\
\text { service recovery. }\end{array}$ \\
\hline $\begin{array}{l}\text { Blomback and Axelsson } \\
\text { (2007) }\end{array}$ & $\begin{array}{l}3 \text { subcontractors and } 6 \text { buyers. } \\
\text { Interviews. }\end{array}$ & $\begin{array}{l}\text { Brand image } \\
\text { Communications } \\
\text { Corporate image }\end{array}$ & Subcontractor selection & $\begin{array}{l}\text { Findings show subcontractor } \\
\text { selection is a process where } \\
\text { buyers initially have little supplier } \\
\text { awareness to but seek information } \\
\text { to build a picture about the } \\
\text { supplier brand. }\end{array}$ \\
\hline Glynn et al. (2007) & $\begin{array}{l}8 \text { New Zealand liquor and } \\
\text { supermarket buyers. } \\
\text { Interviews. }\end{array}$ & $\begin{array}{l}\text { Financial benefits } \\
\text { Marketing support of retailer } \\
\text { Customer expectations, and } \\
\text { Brand equity }\end{array}$ & $\begin{array}{l}\text { Retailers' assessment of brand } \\
\text { satisfaction, trust, commitment, } \\
\text { and performance, cooperation and } \\
\text { dependence. }\end{array}$ & $\begin{array}{l}\text { Manufacturer brands provide } \\
\text { retailer buyers with additional } \\
\text { benefits than just the brand name. } \\
\text { These manufacturer brand } \\
\text { benefits influence several } \\
\text { relationship outcomes. }\end{array}$ \\
\hline Cretu and Brodie (2007) & $\begin{array}{l}377 \text { Salon managers purchasing } \\
\text { hair care supplies. } \\
\text { Survey. }\end{array}$ & $\begin{array}{l}\text { Brand image } \\
\text { Company reputation } \\
\text { Customer loyalty. }\end{array}$ & $\begin{array}{l}\text { Customers' perceptions of product } \\
\text { and service quality, customer } \\
\text { value, and customer loyalty. }\end{array}$ & $\begin{array}{l}\text { Brand's image has a more specific } \\
\text { influence on the customers' } \\
\text { perceptions of product and service } \\
\text { quality while the company's } \\
\text { reputation has a broader influence } \\
\text { on perceptions of customer value } \\
\text { and customer loyalty. }\end{array}$ \\
\hline Lee et al. (2008) & $\begin{array}{l}1000 \text { brand managers ( } 770 \mathrm{~B} 2 \mathrm{C} \\
\text { and } 230 \mathrm{~B} 2 \mathrm{~B} \text { ). } \\
\text { Survey. }\end{array}$ & $\begin{array}{l}\text { Market orientation } \\
\text { Brand management system. }\end{array}$ & $\begin{array}{l}\text { Brand performance - } \\
\text { Customer performance } \\
\text { Financial performance }\end{array}$ & $\begin{array}{l}\text { Brand management systems } \\
\text { (BMS) enhance brand } \\
\text { performance especially for B2B } \\
\text { brands. } \\
\text { Shows a clear link between } \\
\text { market orientation, BMS and } \\
\text { brand performance. }\end{array}$ \\
\hline $\begin{array}{l}\text { Lambkin and Muzellec } \\
\text { (2010) }\end{array}$ & $\begin{array}{l}12 \text { key stakeholders in the merger } \\
\text { of two cement firms. } \\
\text { Case study. }\end{array}$ & $\begin{array}{l}\text { Brand equity } \\
\text { Customer relationships } \\
\text { Product mix sales force } \\
\text { distribution } \\
\text { Networks }\end{array}$ & $\begin{array}{l}\text { Brand equity, and } \\
\text { Know how transfer }\end{array}$ & $\begin{array}{l}\text { Rebranding is useful rationalizing } \\
\text { and integrating an acquired } \\
\text { business. Rebranding signals } \\
\text { positive intent to employees and } \\
\text { stock market. }\end{array}$ \\
\hline Gupta et al. (2010) & $\begin{array}{l}12 \text { in depth interviews with IT } \\
\text { professionals. }\end{array}$ & $\begin{array}{l}\text { Brand knowledge } \\
\text { Brand representative }\end{array}$ & Selection of brand by resellers & $\begin{array}{l}\text { Brand representatives are } \\
\text { important in transferring brand } \\
\text { knowledge to business customers }\end{array}$ \\
\hline
\end{tabular}

relationships with resellers. The brand representative also enhances the buyer understanding and confidence in the brand.

B2B branding research also highlights the influence of individuals outside the firm in the value creation process. Industrial buyers are more likely to seek expert advice or technical advice both from within and outside the firm. For example, architects and engineers are influential in the purchase decision to buy electrical switches (Gordon et al., 1993). To create brand awareness for the B2B brand, personal selling is vital (Bendixen et al., 2004). Bendixen et al. (2004) show that the opinions of technical consultants and sales representatives were more important information sources to the industrial buyer than either advertising and direct mail. In addition to product and quality considerations, the degree of cooperation with the seller and the contact salesperson was also important.

When selecting a new supplier such as a subcontractor, buyers initially often have little information. Research by Blomback and Axelsson (2007) explains that supplier selection processes are sequential, moving from a situation where the customer has little tangible brand information other than awareness through to gathering all the information necessary to make a final decision.

Initial research included reports that the brand name was one of several factors in the B2B purchase and other factors such as price were more important than the brand name. Branding is not necessarily less important in B2B marketing, rather it appears the marketing program is much broader than the traditional marketing mix encompassing intangibles such as corporate support, service and delivery. Thus intangibles which include the actions of employees as well as the opinions of peer and professional networks are important in value creation and are seen by customers as being connected to the $\mathrm{B} 2 \mathrm{~B}$ brand. As there is more direct customer contact in B2B marketing, personal selling also is important and often a B2B buyer's brand image is formed when they are seeking information about the purchase. Next the research on how the B2B branding program affects customers is examined. 


\section{The B2B customer mindset}

The brand marketing program influences the B2B customer mindset and should create brand awareness, brand associations, favorable attitudes and attachment to the brand. Table 2 shows the key research studies as to how the B2B customer mindset is influenced by the brand marketing program and how enduring the connection is between buyers and sellers with respect to the brand.

Building brand awareness is an essential step in the creation of customer-based brand equity. Research in the office products category found that buyers are more likely to choose well known brands when poor decisions could lead to organizational and personal failure (Hutton, 1997).

Another study examines brand awareness as a component of the overall buying decision. In a study of tile resellers, brand awareness was rated third behind perceived quality and loyalty as an influence on reseller profitability, performance and value to the resellers' customers (Baldauf et al., 2003). Davis et al. (2008) found that customers were willing to pay more for logistics service providers with a strong brand name. Supplier image was more important than awareness to industrial customers, however suppliers regarded brand awareness as more important than image.

There are also important psychological differences between consumers and industrial buyers. Industrial buyers also have different predispositions towards branding. Mudambi (2002) found some industrial buyers were branding receptive, while others either had low interest in branding or were more interested in the tangible product aspects. In this research, branding was one of three important decision attributes, along with product and service, and was influenced by both buyer and purchase characteristics. Buyers who were branding receptive were also less influenced by price. Bendixen et al. (2004) found that individuals within the same buying firm view brand attributes differently. For instance product users rate the price attribute as most important, whereas technical specialists rate brand equally with price as being important.

Zablah et al. (2010) also examine the brand receptivity of organizational buyers and considered the effects on brand preference, brand sensitivity and brand importance in the purchase decision. Their study shows when competition was low or was a maintenance decision, marketers should encourage brand consciousness (an awareness of brands within the category). However in a more competitive environment or with high technology purchases, the focus should be on brand preference building for a specific brand (Zablah et al., 2010). Bogomolova and Romaniuk (2010) point out that brand associations among former buyers of a B2B brand may inhibit purchase but those buyers who had never bought had more neutral brand associations. These findings suggest that different marketing approaches may be needed for different customer segments (Bogomolova and Romaniuk, 2010).

The nature of industrial buying involves long term relationships between buyers and sellers. Research shows that consumer marketers have a more transactional focus whereas B2B marketers are more relational in their approach (Coviello et al., 2002). Customer relationship processes for B2B brands enhance buyer identification with the brand, customer contact and loyalty. For example building relationships with channel partners such as chefs enabled marketers to inexpensively build awareness for their meat products in the supply chain (Beverland, 2005). When comparing the separate effects of brand image and corporate reputation, a firm's reputation was more influential on customer loyalty and customer value than the firm's brand image (Cretu and Brodie, 2007). B2B brands enhance the customer's perception of the seller (Michell et al., 2001). The marketing variables that generate brand loyalty were product and service related while advertising and sales force relationships were secondary considerations. In a study of telephone directory advertisers, the personal involvement of the buyer with the category and satisfaction with the service led to increased B2B brand loyalty (Bennett et al., 2005) and spending on the preferred brand.

In Tran and Cox's (2009) study of Vietnamese grocery retailers, manufacturer brand associations were more important in building loyalty than brand trust which also depended on manufacturer support. Brands are also important in building trust for a B2B service (Roberts and Merrilees, 2007). Glynn (2010) examines how supermarket buyers regard manufacturer brands. This research finds that manufacturer brand benefits influence buyer satisfaction and the performance assessment of the brand as well as trust and commitment of the manufacturer's brand. Davis and Mentzer (2008) investigate both brand and trade equity (the equity of a reputable and trustworthy trading partner) and their effects on retailer relationships. Their findings show that brand equity was more likely to affect retailer dependence more than commitment and the interaction of trade and brand equity can weaken retailer commitment to the supplier (Davis and Mentzer, 2008). Some researchers also argue that the emotional aspects of branding are less relevant to business buyers. But one study shows that powertool brands have a symbolic value for builders which is linked to aspirational goals such as accomplishment and job satisfaction (Ringberg and Gupta, 2003).

Kuhn et al. (2008) in a study of electronic waste management systems demonstrate that buyers were sometimes less enthusiastic about a brand and that the sales force were more important in building long term relationships. Co-branding is also a useful strategy that can change the customer mindset. In a study of the wooden floor and floor heating market, co-branding enhanced the credibility of one brand within the selling network, and also increased the trustworthiness of the other brand (Bengtsson and Servais, 2005).

B2B branding research on the customer mindset shows that the creation of brand awareness and brand associations is closely linked to revenue and performance outcomes. B2B buyers also have different levels of receptivity to brands which also depends on the importance of the purchase. In addition, B2B buyers have a longer term orientation and research on brand relationship quality shows that brand associations and involvement with the category enhance customer loyalty to the brand. B2B brand strategies and corporate reputation enhance trust and commitment as well as brand credibility.

\section{B2B brand performance}

Strong brands are important in B2B performance success (Anderson and Narus, 2004). Indicative measures of market performance include price premiums, market share and expansion success. Table 3 shows the extant research that addresses market performance outcomes for B2B brands.

In a study of accounting firms, the adoption of an affiliated "big name" accounting firm led to higher fee revenue (Firth, 1993) as these firms were able to charge a price premium compared to local firms. Persson's (2010) study shows that the client relationship, product offering and service were important in creating a price premium for a B2B brand (Persson, 2010). Bendixen et al. (2004) show that the leading brand of circuit breaker panels was able to command a price premium. Walley et al. (2007) also compared the relative utility of tractor brands and found two leading brands were market assets while other brands were market liabilities.

One study into shopping center leases shows that trust and performance of a shopping center brand was an important consideration for retail tenants when deciding to renew a lease (Roberts and Merrilees, 2007). Han and Sung (2008) show that the supplier's competence is an important determinant of B2B brand value. This brand trust leads to an improved relationship quality and performance perception (Han and Sung, 2008). Recent research across a range of industries (including automotive, chemicals, and machine building) shows that brand awareness significantly affects market 
Table 2

B2B brand customer mindset research.

\begin{tabular}{|c|c|c|c|c|}
\hline Author(s) & Sample & Independent variables & Dependent variables & Key findings \\
\hline Hutton (1997) & $\begin{array}{l}429 \text { national purchasing } \\
\text { association managers. } \\
\text { Survey }\end{array}$ & $\begin{array}{l}\text { Brand reputation, brand } \\
\text { familiarity, a range of buying } \\
\text { conditions including potential } \\
\text { product failure, high service level } \\
\text { for product, complex, not familiar } \\
\text { with category, lack of product } \\
\text { information. }\end{array}$ & $\begin{array}{l}\text { Buyers' willingness to: pay a price } \\
\text { premium for their favorite brand; } \\
\text { recommend that brand to peers; } \\
\text { and give special consideration to } \\
\text { another product with that same } \\
\text { brand name. }\end{array}$ & $\begin{array}{l}\text { The better known the brand was, the } \\
\text { more likely buyers were to exhibit the } \\
\text { three brand-equity behaviors. Major } \\
\text { concerns: organizational failure as a } \\
\text { result of purchase, complexity of } \\
\text { purchase and lack of time or resources to } \\
\text { background purchase. }\end{array}$ \\
\hline $\begin{array}{l}\text { Ringberg and Gupta } \\
\text { (2003) }\end{array}$ & $\begin{array}{l}20 \text { building tradesmen. } \\
\text { Interviews. }\end{array}$ & $\begin{array}{l}\text { Brand trust } \\
\text { Brand affect }\end{array}$ & Business to business loyalty & $\begin{array}{l}\text { Intangibles such as learning, } \\
\text { accomplishment and teamwork helped } \\
\text { achieve job satisfaction and loyalty. }\end{array}$ \\
\hline Baldauf et al. (2003) & $\begin{array}{l}154 \text { tile resellers. } \\
\text { Survey. }\end{array}$ & $\begin{array}{l}\text { Brand awareness } \\
\text { Perceived quality } \\
\text { Brand loyalty }\end{array}$ & $\begin{array}{l}\text { Brand profitability } \\
\text { Brand market performance } \\
\text { Customer perceived value } \\
\text { Purchase intention }\end{array}$ & $\begin{array}{l}\text { Brand loyalty followed by perceived } \\
\text { quality and brand awareness influenced } \\
\text { profitability, performance and value }\end{array}$ \\
\hline $\begin{array}{l}\text { Bengtsson and Servais } \\
\text { (2005) }\end{array}$ & $\begin{array}{l}171 \text { independent distributors of } \\
\text { wooden floor/heating mats. } \\
\text { Case study. }\end{array}$ & $\begin{array}{l}\text { Communication } \\
\text { Trust } \\
\text { Cooperation }\end{array}$ & Attitude to brand & $\begin{array}{l}\text { Shows that distributors can be influenced } \\
\text { by co-branding activities. }\end{array}$ \\
\hline Bennett et al. (2005) & $\begin{array}{l}267 \text { small businesses purchasing } \\
\text { an advertising service. } \\
\text { Survey. }\end{array}$ & $\begin{array}{l}\text { Satisfaction, } \\
\text { Involvement, } \\
\text { Experience. }\end{array}$ & Brand loyalty. & $\begin{array}{l}\text { In high-risk settings category } \\
\text { involvement influence brand loyalty } \\
\text { more than satisfaction. Experience } \\
\text { moderates the influence of involvement } \\
\text { and satisfaction on brand loyalty. }\end{array}$ \\
\hline Beverland (2005) & $\begin{array}{l}6 \text { interviews with farmers, } \\
\text { exporters, design consultant. } \\
\text { Case study. }\end{array}$ & $\begin{array}{l}\text { Branding } \\
\text { Relationships } \\
\text { Market communications } \\
\text { Relationship networks } \\
\text { Push and pull strategies }\end{array}$ & $\begin{array}{l}\text { Development of competitive } \\
\text { advantages }\end{array}$ & $\begin{array}{l}\text { Use of chef network within restaurants } \\
\text { allowed exporter to rapidly develop the } \\
\text { Cervena market. }\end{array}$ \\
\hline $\begin{array}{l}\text { Davis, Golicic and } \\
\text { Marquardt (2008) }\end{array}$ & $\begin{array}{l}142 \text { logistics service providers and } \\
71 \text { customers. } \\
\text { Survey. }\end{array}$ & $\begin{array}{l}\text { Brand awareness, } \\
\text { Brand image. }\end{array}$ & Brand equity. & $\begin{array}{l}\text { Brand image and brand awareness } \\
\text { explained a significant amount of } \\
\text { variance in brand equity. Brand image } \\
\text { was a stronger driver than awareness for } \\
\text { customers. Brand awareness was a } \\
\text { stronger driver of brand equity for } \\
\text { service providers. }\end{array}$ \\
\hline $\begin{array}{l}\text { Davis and Mentzer } \\
\text { (2008) }\end{array}$ & $\begin{array}{l}797 \text { home appliance retailers. } \\
\text { Survey. }\end{array}$ & $\begin{array}{l}\text { Trade equity, } \\
\text { Brand equity. }\end{array}$ & $\begin{array}{l}\text { Supplier dependence, } \\
\text { Supplier commitment. }\end{array}$ & $\begin{array}{l}\text { Brand equity affects dependence more } \\
\text { than commitment. Trade equity is } \\
\text { affected by brand equity. }\end{array}$ \\
\hline Kuhn et al. (2008) & $\begin{array}{l}26 \text { waste management } \\
\text { representatives from local } \\
\text { authorities. } \\
\text { Interviews. }\end{array}$ & $\begin{array}{l}\text { Brand awareness, } \\
\text { Brand elements, } \\
\text { Brand associations, } \\
\text { Judgments, } \\
\text { Brand feelings, } \\
\text { Resonance. }\end{array}$ & $\begin{array}{l}\text { Applicability to Keller } \\
\text { CBBE model }\end{array}$ & $\begin{array}{l}\text { Buyers were more objective, less } \\
\text { advocacy for brand. No brand resonance } \\
\text { evident. Sales force relationships } \\
\text { important }\end{array}$ \\
\hline Tran and Cox (2009) & $\begin{array}{l}355 \text { Vietnamese grocery retailers. } \\
\text { Survey. }\end{array}$ & $\begin{array}{l}\text { Manufacturer support. } \\
\text { Brand association } \\
\text { Brand trust }\end{array}$ & $\begin{array}{l}\text { Brand loyalty } \\
\text { Brand performance }\end{array}$ & $\begin{array}{l}\text { Manufacturer brand associations, trust } \\
\text { and loyalty are all sub-dimensions of } \\
\text { retail brand equity. Brand associations } \\
\text { and loyalty have a positive and } \\
\text { significant effect on brand performance } \\
\text { at the retail level. }\end{array}$ \\
\hline $\begin{array}{l}\text { Baumgarth and } \\
\text { Schmidt (2010) }\end{array}$ & $\begin{array}{l}481 \text { employees survey } 73 \\
\text { employees and management. } \\
\text { Survey }\end{array}$ & $\begin{array}{l}\text { Brand orientation, internal brand- } \\
\text { oriented corporate culture, } \\
\text { internal brand commitment, } \\
\text { internal brand knowledge, } \\
\text { internal brand involvement. }\end{array}$ & $\begin{array}{l}\text { Internal brand equity, } \\
\text { External brand equity. }\end{array}$ & $\begin{array}{l}\text { Internal brand equity is a significant } \\
\text { driver of external B2B brand equity. } \\
\text { Effective business-to-business branding } \\
\text { depends on a brand oriented corporate } \\
\text { culture. Also company-wide involvement } \\
\text { in branding and commitment to the } \\
\text { brand are important drivers of the } \\
\text { internal brand equity. }\end{array}$ \\
\hline Zablah et al. (2010) & $\begin{array}{l}273 \text { organizational buying center } \\
\text { members. } \\
\text { Survey. }\end{array}$ & $\begin{array}{l}\text { Brand consciousness } \\
\text { Brand preference } \\
\text { Brand sensitivity }\end{array}$ & $\begin{array}{l}\text { Brand importance in modified } \\
\text { rebuy situations }\end{array}$ & $\begin{array}{l}\text { In situations of low competitive intensity } \\
\text { brand consciousness is the primary } \\
\text { determinant of brand importance. In } \\
\text { high competitive intensity situations or } \\
\text { when marketing high-tech products, } \\
\text { brand preference is the primary } \\
\text { determinant of brand importance. }\end{array}$ \\
\hline Glynn (2010) & $\begin{array}{l}410 \text { New Zealand supermarket } \\
\text { managers. } \\
\text { Survey. }\end{array}$ & $\begin{array}{l}\text { Manufacturer brand benefits - } \\
\text { manufacturer support, brand } \\
\text { equity, customer expectations. } \\
\text { Brand strength. }\end{array}$ & $\begin{array}{l}\text { Reseller satisfaction with the } \\
\text { brand, performance of brand, trust } \\
\text { in supplier and commitment to } \\
\text { brand. }\end{array}$ & $\begin{array}{l}\text { Customer expectations are important } \\
\text { when resellers evaluate minor brands, } \\
\text { but not for major brands. Minor brands } \\
\text { are more likely to encourage trust } \\
\text { between suppliers and resellers. }\end{array}$ \\
\hline $\begin{array}{l}\text { Bogomolova and } \\
\text { Romaniuk (2010) }\end{array}$ & $\begin{array}{l}504 \text { decision makers selecting } \\
\text { financial suppliers. } \\
\text { Survey. }\end{array}$ & $\begin{array}{l}\text { Positive associations, } \\
\text { Negative associations, } \\
\text { Overall evaluation. }\end{array}$ & $\begin{array}{l}\text { Brand consideration of 'defectors' } \\
\text { and 'never boughts.' }\end{array}$ & $\begin{array}{l}\text { Both defectors and never boughts have } \\
\text { similar purchase propensity. However } \\
\text { defectors have both positive and } \\
\text { negative associations, whereas never } \\
\text { boughts have neutral associations. }\end{array}$ \\
\hline
\end{tabular}


Table 3

B2B brand market performance.

\begin{tabular}{|c|c|c|c|c|}
\hline Author(s) & Sample & Independent variables & Dependent variables & Key findings \\
\hline Firth (1993) & $\begin{array}{l}\text { Time series data } 600 \mathrm{NZ} \\
\text { accounting firms. }\end{array}$ & Brand name of accounting firm & Audit fees & $\begin{array}{l}\text { Using a major accounting firm is } \\
\text { associated with premium audit } \\
\text { fees }\end{array}$ \\
\hline Combs and Ketchen (1999) & $\begin{array}{l}\text { Archival data, and } 226 \text { responses } \\
\text { from an expert panel. }\end{array}$ & $\begin{array}{l}\text { Brand name reputation } \\
\text { Top management team } \\
\text { experience. } \\
\text { Slack capital }\end{array}$ & Interfirm cooperation & $\begin{array}{l}\text { Brand name reputation and } \\
\text { interfirm cooperation were } \\
\text { negatively related. }\end{array}$ \\
\hline $\begin{array}{l}\text { Roberts and Merrilees } \\
\text { (2007) }\end{array}$ & $\begin{array}{l}201 \text { mall tenants. } \\
\text { Survey. }\end{array}$ & $\begin{array}{l}\text { Brand, empowerment, service } \\
\text { quality, responsiveness. }\end{array}$ & Trust, lease renewal. & $\begin{array}{l}\text { Service quality and empowerment } \\
\text { influence brand attitude. } \\
\text { Responsiveness, empowerment } \\
\text { then brand influence trust. } \\
\text { Branding and trust influence lease } \\
\text { renewal. }\end{array}$ \\
\hline Han and Sung (2008) & $\begin{array}{l}279 \text { organizational buyers of } \\
\text { electronics, chemicals and } \\
\text { equipment. } \\
\text { Survey. }\end{array}$ & $\begin{array}{l}\text { Supplier competence, purchasing } \\
\text { value, customer satisfaction, } \\
\text { switching costs, brand trust and } \\
\text { loyalty, relationship quality, } \\
\text { commitment. }\end{array}$ & $\begin{array}{l}\text { Supplier-buyer transaction } \\
\text { performance. }\end{array}$ & $\begin{array}{l}\text { Supplier competence directly } \\
\text { affects purchasing value and } \\
\text { customer satisfaction. This } \\
\text { competence indirectly affects } \\
\text { commitment, switching costs, } \\
\text { brand trust and loyalty. }\end{array}$ \\
\hline Ghosh and John (2009) & $\begin{array}{l}191 \text { engineering managers in OEM } \\
\text { supplier relationships. } \\
\text { Survey. }\end{array}$ & $\begin{array}{l}\text { Vendor investments } \\
\text { Differentiation }\end{array}$ & $\begin{array}{l}\text { Brand contract form } \\
\text { Contract outcome opportunism }\end{array}$ & $\begin{array}{l}\text { Firms choose branded component } \\
\text { contracts when brands add } \\
\text { differentiation and supplier has } \\
\text { customized component }\end{array}$ \\
\hline Persson (2010) & $\begin{array}{l}12 \text { individuals buying corrugated } \\
\text { packaging from Swedish } \\
\text { companies. } \\
\text { Interviews. }\end{array}$ & $\begin{array}{l}\text { Brand familiarity, product } \\
\text { solution, service, distribution, } \\
\text { relationship and company } \\
\text { associations. }\end{array}$ & $\begin{array}{l}\text { Buyers' willingness to pay price } \\
\text { premiums }\end{array}$ & $\begin{array}{l}\text { Relationship, product solution and } \\
\text { service were most important in } \\
\text { relation to a price premium. } \\
\text { Distribution, company and } \\
\text { familiarity were of lesser } \\
\text { importance. }\end{array}$ \\
\hline Homburg et al. (2010) & $\begin{array}{l}310 \text { marketing managers, cross } \\
\text { industry sample. } \\
\text { Survey. }\end{array}$ & $\begin{array}{l}\text { Brand awareness - } \\
\text { Recognition, recall, top-of-mind, } \\
\text { brand knowledge }\end{array}$ & $\begin{array}{l}\text { Market performance - } \\
\text { Customer loyalty, acquisition of } \\
\text { new customers, achievement of } \\
\text { desired market share, } \\
\text { achievement of desired growth }\end{array}$ & $\begin{array}{l}\text { Brand awareness drives market } \\
\text { performance. The relationship is } \\
\text { stronger in markets with } \\
\text { homogenous buying centers, } \\
\text { greater buyer time pressure, } \\
\text { homogenous products, and a high } \\
\text { degree of technological } \\
\text { turbulence. }\end{array}$ \\
\hline
\end{tabular}

performance especially in conditions of product uniformity, time pressure and technological turbulence (Homburg et al., 2010).

However some writers particularly from a distribution channel perspective suggest a positive brand mindset does not always mean a favorable outcome for the seller. Inter-firm relationships, while creating strategic advantage, also have their costs such as the loss of firm bargaining power and exposure to opportunism. Relationships with B2B buyers such as retailers can mean the loss of control for retailers as manufacturers support their brands in the marketplace as a whole which benefits competing retailers. Combs and Ketchen (1999) emphasize the value of resource sharing because together manufacturers and buyers both perform value creation functions that no one firm can complete individually (Combs and Ketchen, 1999). Firms with less brand equity have fewer resources and are more likely to engage in inter-firm cooperation than firms with strong brands.

Glynn (2010) compares how two different market outcomes, high brand equity and low brand equity, influence retailer's attitudes and performance assessment. A multi-group analysis of the high and low equity brands shows that retailers are more likely to commit and likely to trust low equity brands more than high equity brands (Glynn, 2010). A reason given in the qualitative responses is that retailers use minor brands to counter the strength of leading brands within the category. Retailers were not as committed to the strong brands as retailers thought customers expected these brands to be part of the retailers range anyway. Meanwhile minor brands had fewer resources and needed to encourage retailer support to achieve the necessary distribution intensity.

Ghosh and John (1999) highlight a value creation problem for B2B brands in firm exchanges. Once the value is created for a B2B brand, both buyers and sellers try to minimize their stake by reducing their investment in the relationship. These authors consider that the firm resources such as technology, customer (brand equity) and supply chain partners give access to marketplace positions which are valued by customers and influence the governance form and either short or long term exchanges (Ghosh and John, 1999). Ghosh and John's (2009) research shows a further role for the B2B brand as a governance mechanism, protecting supplier investments in the customer.

Few research studies focus on the marketplace effects of B2B branding. Some research shows that leading B2B brands can command a price premium and that a favorable customer mindset can influence performance perceptions. Some research examines the effects of business relationships and governance on brand equity outcomes. Several B2B branding studies show the effect of channel support as a multiplier of market performance in the brand value chain.

\section{Conclusion}

The Interbrand list demonstrates the high brand dollar value of many B2B brands. A key difference between B2C and B2B marketing is the emphasis on longer-term corporate relationships and not one off transactions. The consumer psychology approach of B2C branding research does not completely address the multidimensional nature of a B2B brand in creating value between firms. Brands are an important resource and a source of value for industrial organizations. While many B2B branding studies use B2C frameworks, alternatives exist that focus on brands as a resource (Srivastava et al., 1998). While B2B firms ensure the product meets the buyer's specification through attention to the product attributes and benefits, such transactions have a long-term component for buyers and sellers. These alternative frameworks show the effects of multipliers such as channel support 
and interfirm relationships on B2B brands and the importance of other stakeholders. B2B purchasing within supply chains shows how brands can enhance the customer's business particularly when firms have complementary resources. The resource-based view of the firm which regards brands as a market-based asset emphasizes the importance of interorganizational relationships for B2B customers.

The initial focus of early B2B brand studies was on whether or not firms should spend marketing funds on branding. Much B2B branding research examines the marketing program showing a wide range of brand related benefits are important to industrial buyers. Fewer studies investigate the effects of brand marketing on the B2B customer. However research illustrates the importance of B2B branding in customer relationship management. Research into the performance of B2B brands indicates that leading brands create price premiums and can enhance relationships. Furthermore, strong customer relationships can be beneficial to minor brands.

Further research should identify the circumstances where B2B brands can be a potential cost (rather than a benefit) to customers. Research into product and service processes could also explore how B2B branding enhances the B2B customer mindset. B2B branding effects should be considered against a wider set of relationship outcomes other than customer satisfaction and loyalty. Research could also investigate the usefulness of B2B brands in acquiring customers, customer retention, customer education, extracting or minimizing price concessions, and providing customer solutions. The contribution of B2B brands on market performance needs to be explicitly examined alongside these other firm resources. In addition, the role of B2B brands in the broader organizational context needs further exploration examining issues such as cost minimization, channel conflict and channel cooperation.

\section{Practicum in business-to-business brand-building strategies}

\subsection{Chorus}

In March 2008 Telecom New Zealand Ltd., a New Zealand telecommunications firm, launched a new brand: Chorus, its network division. Previously the New Zealand Government had required Telecom to split into three separate divisions: Telecom Retail, Telecom Wholesale and the network business. This split was necessary to encourage more network competition amongst telecommunication providers for phone, mobile, data and internet services. Telecom's network controls $93 \%$ of the fixed line access in the country. This network includes telephone exchanges, copper and fiber cables to connect 1.8 million New Zealand homes and businesses. As part of this split, the company was required to create a distinct identity for the network division.

The network division connects other competing telecommunications firms to the Telecom network as well as allowing competitors to install the necessary communications equipment onto its landline and mobile phone networks. Commenting on the new name for the network division of Telecom, the CEO of Chorus Mr. Mark Ratcliffe said the new name reflects a broader industry perspective and is more personal. Ratcliffe said. "It's a nice word. It's hard to think about Chorus as being anything other than positive and enthusiastic", he said. "We wanted something to reflect that we are a customer-centric service organization and that we were collaborative", said Ratcliffe.

In the United Kingdom, a rebranding of British Telecom's (BT) network division to Openreach caused confusion for some customers who were expecting BT branded vans to appear when telecommunication faults were being fixed. The new brand appears on the field service vans used by Telecom's main service partners, Transfield Services, Downer Engineering and Visionstream. On these vans, the words "A Telecom New Zealand Business" appear beneath the Chorus logo. The new branding also identifies the service technicians who install phones, repair and carry out line and wiring maintenance throughout New Zealand.
In addition, to overcome any further customer concern Telecom implemented an extensive television advertising campaign about the new Chorus brand. A series of television commercials emphasizes the extensive coverage of rural areas, the firm's efforts in providing highspeed broadband fiber, their expertise in telecommunication networks and providing an equivalent level of service for all business customers including Telecom's retail competitors.

\section{Discussion questions:}

1. Discuss the relevance of the Chorus brand marketing program for business-to-business customers.

2. In what ways do you think the customer mindset will be influenced by this campaign?

3. Critique the marketing approach of Chorus in building longer-term business customer relationships.

4. How do you think the rebranding will influence market performance for Chorus?

\section{References}

Anderson JC, Narus JA. Business market management: understanding, creating and delivering value. 2nd ed. Upper Saddle River, NJ: Prentice Hall Inc.; 2004.

Baldauf A. Cravens KS, Binder G. Performance consequences of brand equity management: evidence from organizations in the value chain. J Prod Brand Manage 2003;12(4):220-36

Ballantyne D, Aitken R. Branding in B2B markets: insights from the service-dominant logic of marketing. Journal of Business \& Industrial Marketing 2007;22(6):363-71.

Baumgarth C, Schmidt M. How strong is the business-to-business brand in the workforce? An empirically-tested model of 'internal brand equity' in a business-tobusiness setting. Ind Mark Manage 2010;39(8):1250-60.

Bendixen M, Bukasa KA, Abratt R. Brand equity in the business-to-business market. Ind Mark Manage 2004;33(5):371-80.

Bengtsson A, Servais P. Co-branding on industrial markets. Ind Mark Manage 2005;34(7):706-13.

Bennett R, Hartel CEJ, McColl-Kennedy JR. Experience as a moderator of involvement and satisfaction on brand loyalty in a business-to-business setting. Ind Mark Manage 2005;34(1):97-107.

Beverland M. Creating value for channel partners: the Cervena case. J Bus Ind Mark 2005;20(3):127-35.

Blomback A, Axelsson B. The role of corporate brand image in the selection of new subcontractors. J Bus Ind Mark 2007;22(6):418-30.

Bogomolova S, Romaniuk J. Brand equity of defectors and never boughts in a business financial market. Ind Mark Manage 2010;39(8):1261-8.

Brodie RJ, Glynn MS, Little V. The service brand and the service-dominant logic: missing fundamental premise or the need for stronger theory? Mark Theory 2006;6(3): 363-79.

Combs JG, Ketchen Jr DJ. Explaining interfirm cooperation and performance: toward a reconciliation of predictions from the resource-based view and organizational economics. Strateg Manage J 1999;20(9):867-88.

Coviello NE, Brodie RJ, Danaher PJ, Johnston WJ. How firms relate to their markets: an empirical examination of contemporary marketing practices. J Mark 2002;66(3): 33-46.

Cretu AE, Brodie RJ. The influence of brand image and company reputation where manufacturers market to small firms: a customer value perspective. Ind Mark Manage 2007;36(2):230-40.

Davis DF, Golicic SL, Marquardt AJ. Branding a B2B service: does a brand differentiate a logistics service provider? Ind Mark Manage 2008;37(2):218-27.

Davis DF, Mentzer JT. Relational resources in interorganizational exchange: the effects of trade equity and brand equity. J Retailing 2008;84(4):435-48.

Firth M. Price setting and the value of a strong brand name. Int J Res Mark 1993;10(4): 381-6.

Ford D. Managing business relationships. Chichester [England]; New York: Wiley; 1998

Ghosh M, John G. Governance value analysis and marketing strategy. J Mark 1999;63: 131-45 (Special Issue).

Ghosh M, John G. When should original equipment manufacturers use branded component contracts with suppliers. J Mark Res 2009;46(5):597-611.

Glynn MS. The moderating effect of brand strength in manufacturer-reseller relationships. Ind Mark Manage 2010;39(8):1226-33.

Glynn MS, Motion JM, Brodie RJ. Sources of brand benefits in manufacturer-reseller B2B relationships. J Bus Ind Mark 2007;22(6):400-9.

Gordon GL, Calantone RJ, di Benedetto CA. Brand equity in the business-to-business sector: an exploratory study. J Prod Brand Manage 1993;2(3):4-16.

Gregory JR, Sexton DE. Hidden wealth in B2B brands. Harv Bus Rev 2007;85(3):23.

Gupta S, Melewar TC, Bourlakis M. Transfer of brand knowledge in business-to-business markets: a qualitative study. J Bus Ind Mark 2010;25(5):395-403.

Han S-L, Sung H-S. Industrial brand value and relationship performance in business markets a general structural equation model. Ind Mark Manage 2008;37(7):807-18.

Homburg C, Klarmann M, Schmitt J. Brand awareness in the business markets: when is it related to firm performance? Int J Res Mark 2010;27(3):201-12. 
Hutton JG. A study of brand equity in an organisational buying context. J Prod Brand Manage 1997;6(6):428-39.

Interbrand. Best global brands 2010; 2010.

Keller KL. Strategic brand management: building, measuring, and managing brand equity. 3rd Ed. Upper Saddle River, N.J.: Prentice Hall; 2008

Keller KL, Lehmann DR. How do brands create value? Mark Manage 2003;12(3):26-31.

Kotler P, Pfoertsch W. B2B brand management. Berlin; New York: Springer; 2006.

Kuhn KA, Alpert F, Pope N, Ll K. An application of Keller's brand equity model in a B2B context. Qual Market Res Int J 2008;11(1):40-58.

Lambkin MC, Muzellec L. Leveraging brand equity in business-to-business mergers and acquisitions. Ind Mark Manage 2010;39(8):1234-9.

Lamons B. The case for B2B branding: pulling away from the business to business pack 1st ed. Mason, Ohio: Thomson/South-Western; 2005.

Lee J, Park SY, Baek I, Lee C-S. The impact of the brand management system on brand performance in B-B and B-C environments. Ind Mark Manage 2008;37(7):848-55.

Madden TJ, Fehle F, Fournier S. Brands matter: an empirical demonstration of the creation of shareholder value through branding. J Acad Mark Sci 2006;34(2): 224-35.

McQuiston DH. Successful branding of a commodity product: the case of RAEX LASER steel. Ind Mark Manage 2004;33(4):345-54.

Merz MA, He Y, Vargo SL. The evolving brand logic: a service-dominant logic perspective. J Acad Mark Sci 2009;37(3):328-44.

Michell P, King J, Reast J. Brand values related to industrial products. Ind Mark Manage $2001 ; 30(5): 415-25$

Mudambi S. Branding importance in business-to-business markets; three buyer clusters. Ind Mark Manage 2002;31(6):525-33.

Mudambi SM, Doyle P, Wong V. An exploration of branding in industrial markets. Ind Mark Manage 1997;26:433-46.

Persson N. An exploratory investigation of the elements of B2B brand image and its relationship to price premium. Ind Mark Manage 2010;39(8):1269-77.

Ringberg T, Gupta SF. The importance of understanding the symbolic world of customers in asymmetric business-to-business relationships. J Bus Ind Mark 2003;18(6/7): p607-26.
Roberts J, Merrilees B. Multiple roles of brands in business-to-business services. J Bus Ind Mark 2007;22(6):410-7.

Rosenbröijer C-J. Industrial brand management: a distributor's perspective in the UK fine-paper industry. J Prod Brand Manage 2001;10(1):7-25.

Saunders J, Watt FA. Do brand names differentiate identical industrial products? Ind Mark Manage 1979;8(2):114-23.

Selnes F. An examination of the effect of product performance on brand reputation. Eur J Mark 1993;27(9):19-35.

Shaw J, Giglierano J, Kallis J. Marketing complex technical products: the importance of intangible attributes. Ind Mark Manage 1989;18(1):45-53.

Shipley D, Howard P. Brand-naming industrial products. Ind Mark Manage 1993;22(1): 59-66.

Simon CJ, Sullivan MW. The measurement and determinants of brand equity. Mark Sci 1993;12(1):28-52.

Sinclair SA, Seward KE. Effectiveness of branding a commodity product. Ind Mark Manage 1988;17(1):23-33.

Srivastava RK, Shervani TA, Fahey L. Market-based assets and shareholder value: a framework for analysis. J Mark 1998;62(1):2-18.

Tran Q Cox C. Building brand equity between manufacturers and retailers. In: Glynn MS, Woodside AG, editors. Business-to-business brand management: theory, research and executive case study exercises, Vol. 15. Bingley: Emerald Group Publishing Limited; 2009. p. 115-94.

van Riel ACR, Pahud de Mortanges C, Streukens S. Marketing antecedents of industrial brand equity: an empirical investigation in specialty chemicals. Ind Mark Manage 2005;34(8):841-7.

Vargo SL, Lusch RF. Evolving to a new dominant logic for marketing. J Mark 2004;68(1):1-17.

Walley K, Custance P, Taylor S, Lindgreen A, Hingley M. The importance of brand in the industrial purchase decision: a case study of the UK tractor market. J Bus Ind Mark 2007;22(6):383-93.

Yanamandram V, White L. Switching barriers in business-to-business services: a qualitative study. Int J Serv Ind Manage 2006;17(2):158-92.

Zablah AR, Brown BP, Donthu N. The relative importance of brands in modified rebuy purchase situations. Int J Res Mark 2010;27(3):248-60. 